\title{
The operation of the last stage of steam turbine at low-flow rate modes
}

\section{A. L. Shubenko,}

\section{N. Goloshchapov,}

\section{O. Senetska}

A. N. Podgorny Institute of Problems of Mechanical Engineering NAS Ukraine, 2/10 Pozharskogo St., 61046 Kharkiv, Ukraine

Email: dasha.seneckaya@gmail.com
At the present time, thermal power plants and combined heat and power plants operate in highly manoeuvrable modes with almost daily deep unloading, shutdowns on weekends and holidays followed by launches from various thermal conditions. During start-ups, the operation at partial modes and shutdowns, the turbine flow path operates at low-flow rate modes and, as a result, varying tear-off phenomena appear depending on a relative volumetric flow rate of steam $\overline{G v}_{2}$ in the low-pressure cylinder starting from the last stage.

This is especially true for the operation of the low-pressure path for cogeneration turbines. Under low-flow rate modes a change in the flow structure occurs accompanied by the appearance of the bushing tear-off, the rotating vortex in the gap between stator blades and rotor blades, and an increase in pressure in the main flow when switching to the operation at the compressor mode.

The formation of the tear-off area is accompanied by a significant increase in the temperature of steam during its overheating due to ventilation losses created by vortex structures in the areas of tear-off.

The temperature change along the working blade length is considered, the characteristic points of this change depending on the relative volumetric flow rate of steam are highlighted.

The boundaries of transition from the wet steam to the superheated steam with decreasing $\overline{G v}_{2}$ are determined.

The power consumption for the operation of the stage with a decrease in the flow rate of steam and a change in the flow structure is considered.

Keywords: turbine stage, low flow rate mode, temperature steam, power consumption

\section{INTRODUCTION}

The idle mode is allowed for no more than one hour for condensing turbines and, as an exception, during a day when commissioning works on the generator. The operation of the low-pressure cylinder (LPC) with a closed regulating diaphragm for cogeneration turbines during a heating period and the steam consumption, which is necessary to remove the heating of steam in 
the blades apparatus, resulting from ventilation losses, is characteristic. As shown by the operating experience of turbines and experimental studies of the operation of stages with a small bushing ratio in a wide range of modes changes, tear-off phenomena are formed in them, accompanied by vortex formation which leads to a decrease of the turbine flow path efficiency and to a significant increase of the temperature of rotor blades (RB) and stator blades (SB). Therefore, the study of processes occurring in the stages of LPC at various volumetric flow rates of steam, corresponding to low-flow rate modes, is an urgent task [1-4].

To ensure a reliable operation of the blades apparatus of LPC, it is necessary to have a clear idea of moisture formation processes, the structural changes in the flow associated with the process of transition from the wet to the superheated steam due to ventilation losses at partial modes.

\section{FLOW PHENOMENA OF THE WORKING MEDIUM IN THE STAGES OF LPC AT LOW-FLOW RATE MODES}

For the stages of LPC of cogeneration turbines during operation in a wide range of modes changes, due to changes in the temperature state it is necessary to form additional requirements for monitoring their thermal state both for diagnostics and for the rational operation of the cooling system. Currently, the cogeneration turbines mainly use cooling systems for the outlet branch pipes, which under low-flow rate modes have a little effect on the temperature state of the blades apparatus of the last stage. At the same time, in the rim clearance of the last stages, the level of temperatures can reach values at which the soldered anti-erosion plates break away.

Most studies of physical processes occurring in the low-pressure cylinder of cogeneration turbines are devoted to obtaining the integral characteristics of stages at small values of relative volumetric consumptions and to assessing the effect of changes of the pressure in the condenser on them.

To analyse the operation of stages at the lowflow rate modes, it is advisable to use the relative volumetric flow rate of steam as a criterion $\bar{G} v_{2}$, which is the ratio of volumetric flow rate of steam
$V_{2}$ in the considered mode to the volumetric flow rate of steam $V_{2 \text { nom }}$ at the nominal mode of stage operation corresponding to the maximum efficiency on the rim of stage

$$
\overline{G v_{2}}=\frac{G v_{2}}{G v_{2 \text { nom }}}=\frac{V_{2}}{V_{2 \text { nom }}},
$$

where $G$ is the mass flow rate of steam through the stage, and $v_{2}$ is the specific volume of steam behind the rotor blades.

Let us consider the operation of the last stage at the low-flow rate mode. The flow structure obtained by the authors of the calculation in LPC of the T-250/300-240 turbine for three operating modes at $\overline{G v}_{2}$ and at the pressure in the condenser $P_{c}[1]$ are shown in Fig. $1(\mathrm{a}-\mathrm{c})$. As the boundaries separating the main flow of steam from the tearoff areas, the values $\bar{G}=G / G_{0}$, which correspond to the values $\bar{G}=0$ for the area of tear-off and $\bar{G}=1.0$ for the area of rotating vortex in the rim clearance of stage, are taken and $G_{0}$ is the steam consumption at the entrance to the stage. It can be seen that an intense bushing tear-off was formed, the beginning of which is located at the exit edge of working blade of the 29th stage. It is formed by processes occurring in the penultimate stage. The bushing tear-off in the last stage develops taking into account the rise of flow created by RB of the penultimate stage, i.e. it is through. Thus, the last stage can be considered as consisting of two areas:

- the upper with a relatively short blade in which the main steam flow enters the stage;

- the lower in which there is a process of formation of purely ventilation losses in the form of bushing tear-off behind blades of RB and a vortex before entering the channels of RB.

The bushing tear-off in the penultimate stage was formed under the action of RB of the 29th stage and captures the stator blades of the 30th stage. In this case, an intense rotating vortex also arises in its rim clearance and increased losses create a mode in which the stage consumes power.

When LPC is operating in this mode $\left(\bar{G} v_{2}=\right.$ 0.05 , which corresponds to the fully closed rotary part of the regulating diaphragm, i.e. the rotary ring is in the 'on' position), the steam enters the flow path through leaks between the rotary ring and the diaphragm. With a small mass flow 




Fig. 1. The position of tear-off areas in the flow path of LPC:

(a) $\bar{G} v_{2}=0.305, P_{c}=8 \mathrm{kPa}$; (b) $\bar{G} v_{2}=0.087, P_{c}=5 \mathrm{kPa} ;(c) \bar{G} v_{2}=0.05, P_{c}=12 \mathrm{kPa}$

rate of steam it is discarded by centrifugal force to the periphery and the working blades create a large peripheral velocity of steam with its subsequent release into the rim clearance, which supports the rotation of vortex.

Thus, the formed flow structure in LPC stages has a significant effect on both the energy losses in them and the dynamic state of working blades.

To maintain vortex structures energy is expended, supplied by the rotor to the working blades, which, as a result of increased turbulence, turns into heat. In the stage the energy of rotating vortex structure is exchanged with the main flow occurring through $\mathrm{RB}$ with a transition to a larger radius.

\section{THE TEMPERATURE STATE OF THE LAST STAGES}

The temperature measurement at the outlet edges of working blades of the last stages of LPC of the T-250/300-240 turbine was carried out at 
the full-scale stand of the Ural Turbine Plant [5]. The results are processed by the authors of this publication with reference to $\bar{G} v$, which varies depending on the pressure $P_{c}$ in the condenser, and are shown in Fig. 2.

Operation in the stage at the low-flow rate mode occurs during the transition from power generation to its consumption, i.e. at the idle mode. For each stage of LPC of the turbine, the idle mode occurs when [1]

$$
\begin{aligned}
& \overline{G v}_{\text {idle }}=1.071 \cdot\left(1.0-r_{\text {bush }}^{-2}\right) \cdot\left(\operatorname{tg} \beta_{2}^{\text {mid }}\right. \\
& \left.-0.087 \operatorname{tg} \gamma_{o}+0.197\right)
\end{aligned}
$$

where $\bar{r}_{\text {bush }}=r_{\text {bush }} / R_{0}$ is the relative radius of bushing, $\beta_{2}^{\text {mid }}$ is the outlet angle of flow from RB on the middle diameter, and $\gamma_{0}$ is the tilt angle of outer meridional contour.

The transition to the idle mode also depending on the geometric characteristics of stage can be presented.

The stage operates with the wet steam before the idle mode, the transition to the power consumption mode leads to the fact that part of energy of ventilation losses is spent on the evaporation of finely dispersed moisture, which causes a shift in the transition boundary from the steam condensation temperature to its superheat temperature.
The experimentally obtained temperature distribution along the length of working blade at the full-scale stage under low-flow rate modes [5], which is shown in Fig. 2, corresponds to the area of superheated steam. The steam overheating occurs due to a high level of ventilation losses.

In Fig. 2(a), the inset shows the temperature change along the length of blade, where dots indicate characteristic values. So, point 1 characterizes the temperature of rotating vortex; point 2 characterizes the temperature of main flow, taking into account mixing of the medium from the rotating vortex (this is the minimum temperature); point 3 characterizes the temperature, taking into account the increase in the vortex and the influence of bushing take-off; point 4 characterizes the temperature of inflowing medium in the vortex, which is formed in the bushing tear-off.

The effect of steam consumption on its temperature at characteristic points is shown in Fig. 2(a), the effect of pressure in the condenser is shown in Fig. 2(b).

A linear effect of these parameters on the temperature level at characteristic points is observed, which is caused by both a change of mass at a constant volumetric flow rate of steam (Fig. 2(a)) and a change of pressure in the condenser, which in accordance with the steam state equation affects the change of a specific volume at a constant consumption (Fig. 2(b)). A feature of the effect $P_{c}$ is

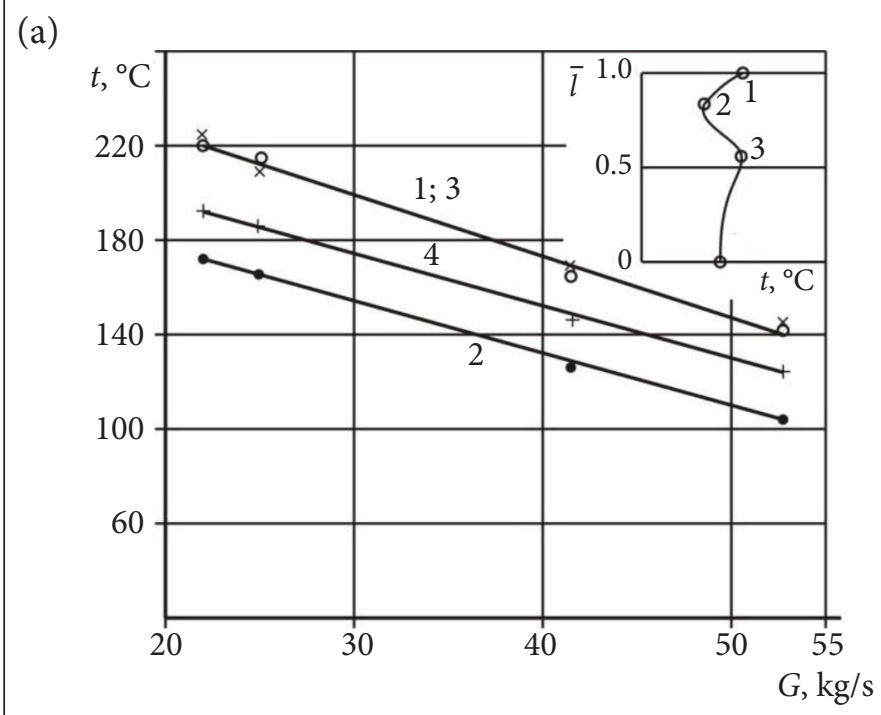

(b)

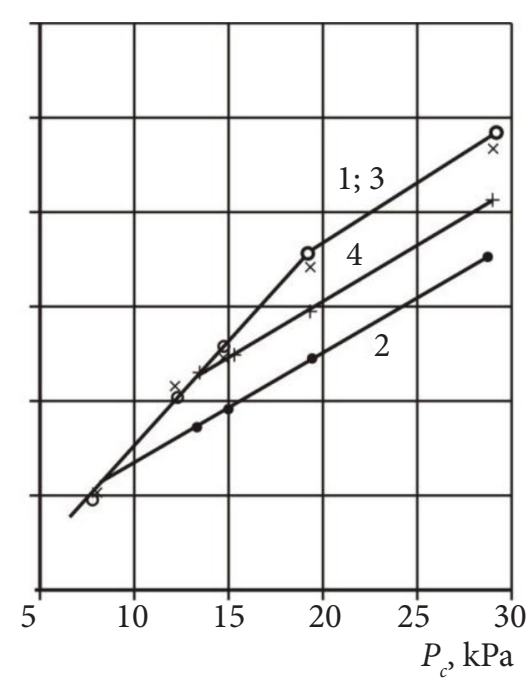

Fig. 2. The effect of steam consumption $G$ at $P_{c}=29.4 \mathrm{kPa}$ (a) and the pressure in the condenser $P_{c}$ at $G=24.7 \mathrm{~kg} / \mathrm{s}(\mathrm{b})$ on the change of steam temperature in the stage 
the change of the pace of temperature increase at the break points of dependence.

The change in the maximum temperature of characteristic points 1 and 3 for the last stage (31st) of T-250/300-240 turbine depending on $\overline{G v}_{2-31}$, where number 31 indicates the number of the stage under investigation, is shown in Fig. 3. The dashed lines show the area of wet steam, the solid lines show the area of steam overheating with decreasing $\overline{G v} v_{2}$, and the line A-A corresponds to the end of moisture evaporation at different pressures in the condenser. The steam overheating caused by losses in the rotating vortex and losses in the bushing tear-off (branch pipe cooling is turned off) increases significantly with decreasing $\overline{G v}_{2}$ and for the last stages of LPC at $\bar{G} v_{2}=0.05$ can reach the temperature $240-320^{\circ} \mathrm{C}$.
The steam heating in the last stage can be characterized by a varying pace depending on $\bar{G} v_{2}$ and is divided into two areas:

- at $\overline{G v} v_{2}$ to the right of the line B-B (the area between the boundary lines $A-A$ and $B-B$ );

- at $\overline{G v}{ }_{2}$ to the left of the line B-B.

With increasing pressure $P_{c}$ in the condenser, the losses in stages are increasing, which leads to an increase in the power consumption of LPC stages.

The power consumption of stage occurs when the stage goes into the idle mode, but since the stage operates in the wet steam, after reaching this mode, the losses associated with the tear-offs and turning into heat are spent on the evaporation of dispersed moisture. Therefore, up to the boundary A-A in Fig. 3, the steam



Fig. 3. The change of maximum temperature at the outputting edge of working blade of the last stage of LPC of the T-250/300-240 turbine under power consumption modes

* 1 is $t_{s}=68.16^{\circ} \mathrm{C}, P_{c}=29.4 \mathrm{kPa} ; \times 2$ is $t_{s}=63.64^{\circ} \mathrm{C}, P_{c}=24.5 \mathrm{kPa} ; \Delta 3$ is $t_{s}=58.52^{\circ} \mathrm{C}, P_{c}=19.6 \mathrm{kPa}$;

$\Delta 4$ is $t_{s}=52.52^{\circ} \mathrm{C}, P_{c}=14.7 \mathrm{kPa} ; \circ 5$ is $t_{s}=45.1^{\circ} \mathrm{C}, P_{c}=0.8 \mathrm{kPa} ; \bullet 6$ is $t_{s}=36.69^{\circ} \mathrm{C}, P_{c}=5.7 \mathrm{kPa}$ 
temperature still corresponds to the saturation temperature determined by the pressure $P_{c}$ behind the stage. If the idle mode for the last stage of T-250/300-240 turbine occurs at $\overline{G v}_{2}=0.54-$ 0.56 , then the transition from the wet steam to the superheated steam depending on the pressure $P_{c}$ in the condenser changes from $\bar{G} v_{2} \approx 0.33$ to $\approx 0.45$, and only after that, the steam temperature rises sharply due to the heating of mechanical losses in the rotating tear-offs. At the same time, the rotating vortex makes a significant contribution to the temperature increase in the rim clearance, since the cold steam from the condenser is sucked into the bushing tear-off.

The position of boundary line A-A depends on the pressure $P_{c}$ in the condenser and has a break at $P_{c}=19.6 \mathrm{kPa}$. At this boundary, the transition from the wet steam to the overheated steam is completed.

The position of the line A-A can be represented by the dependencies:

- at $5.7 \leq P_{c} \leq 19.6 \mathrm{kPa}, t^{b}=22.738+1.5705 \cdot P_{\dot{c}}$

- at $19.6 \leq P_{c} \leq 30 \mathrm{kPa}, t^{b}=40.0+0.9451 \cdot P_{c}$.

For the boundary line $\mathrm{B}-\mathrm{B}$, after which there is a change of the pace of increase in the temperature of steam, the dependence $t^{b} \sim P_{c}$ takes the form $t^{b}=82.0+2.89 \cdot P$ and the relative volumetric flow rate of steam $\left(\overline{G v_{2}}\right)^{b}=0.2088+0.0014346 \cdot P_{c}$, where the pressure $P_{c}$ varies in the range $5.7 \leq P_{c} \leq 29.4 \mathrm{kPa}$.

As the pressure $P_{c}$ increases at $G=$ const, the volume consumption $\overline{G v}{ }_{2}$ due to a decrease of $v_{2}$ is decreasing and the area of root tear-off flow behind the working blades of stages is increasing. Moreover, an increasing part of the blade height is occupied by the 'reverse' flow in the area of bushing tear-off directed towards the working blades. At the same time, the operation of upper sections is going to be worse. In the middle sections of the working blades of stage there is an active flow with the useful use of flow energy. A further increase in $P_{c}$ leads to a decrease in this area and the appearance of tear-off flows in the peripheral sections.

Thus, as follows from the foregoing, it can be stated that the low-flow rate modes in which the operation of flowing path of LPC is accompanied by the generation of heat losses due to friction during ventilation are observed during start-ups, the idle mode and for cogeneration turbines at high heat loads. When the turbine is operating according to a thermal schedule with the minimum steam consumption, the permissible thermal state of LPC vanes is maintained by passing through the flowing path of the cooling steam. The optimal consumption of this steam is determined by the temperature state of blade apparatus, the mounted discs, the erosive loads on the input edges of regulating stage blades, as well as the efficiency of turbine and the vibration state of blades of the last stages with certain ratios $\overline{G v}_{2}[6-8]$. The presence of droplet structures in the flowing path during the operation of the turbine with a serial cooling system significantly increases the cooling potential of steam in the outlet branch pipes of LPC, but often creates drop-like loads on the outlet edges of working blades of the last stages in the area near the root of the blade.

The thermal state of stage with a small ratio $D_{\text {mid }} / l_{\mathrm{rb}}\left(l_{\mathrm{rb}}\right.$ is the working blade length, $D_{\text {mid }}$ is the middle diameter of $\mathrm{RB}$ ) at the low-flow rate mode is determined by three types of processes that occur in the stage with decreasing $\overline{G v}$.

The first process. At a decrease $\overline{G v} v_{2}$ after passing through the idle mode, the flow behind RB, detached from the bushing under the influence of swirling, is rising within the rotor blades, which takes the rotor energy. For a flow moving in $\mathrm{RB}$ channels in the radial direction with increasing the output radius, this process is compressor, i.e. energy consuming. With a decrease in volumetric consumption, the outlay of steam compression determined by the Euler formula increases.

The second process is the development of bushing tear-off, the boundary of which $\bar{G} v_{2} \leq\left(\overline{G v}_{2}\right)_{\text {idle }}$ develops inside RB channels. At the same time, the area of outlet edges begins to work as a fan which is sucking the steam from the bushing tear-off area near the bushing. The surfaces of blades carry it in the radial direction and output near the peripheral area into the cavity behind the working blades with a sufficiently large peripheral velocity component. The bushing take-off behind RB is connected to the condenser from where the partially cooled steam enters with the return current into the area of output edges of RB.

The third process is the appearance and development of vortex rotating in the rim clearance of the stage. The origin of the vortex occurs after 
the formation of bushing tear-off. At a decrease $\overline{G v}{ }_{2}$ the rotating vortex develops towards the bushing and at $\overline{G v} \approx 0.05$ it occupies $~ 95 \%$ of the working blade length.

The formation of these processes at the stage is confirmed by the distribution analysis of component velocities in the rim clearance and beyond $\mathrm{RB}$ obtained experimentally on a model single-stage turbine [1] and shown in Fig. 4.

The axial projection of velocity (Fig. 4(a)) in the rim clearance $\bar{C}_{2 z}=\mathrm{C}_{1 z} / U_{\mathrm{Ro}}$, where $U_{\mathrm{Ro}}$ is the peripheral velocity of working blades on the outer radius $R_{\mathrm{o}}$, in the peripheral area of rim clearance has the area of negative values varying from the values of $\bar{C}_{1 z}=-0.25$ on the outer radius to $\bar{C}_{1 z}=0$ at $\bar{l} \approx 0.89$. Negative values correspond to the discharge of working fluid from RB channels into the rim clearance.

The value $\bar{C}_{1 z}$ measured in the rim clearance, on the most of rotating vortex $\bar{C}_{1 z} \approx 0$ and only in the area near the root of the blade, becomes positive (directed towards channels of RB).

The axial component of velocity $\bar{C}_{2 z}$ behind $\mathrm{RB}$ is negative in the most of working blade (up to $\bar{l} \approx 0.85$ ). In the peripheral area, the value $\bar{C}_{1 z}$ acquires a positive value and through the area of $\sim 0.15 \bar{l}$ the steam consumption of the main flow entering the stage input and the flow coming from the area of bushing tear-off is passed.
The change of a peripheral velocity component in the rim clearance $\bar{C}_{1 u}$ (Fig. $4(\mathrm{~b})$ ) is caused by the rotating vortex, this is the maximum level of $\bar{C}_{1 u}$ in the peripheral area of rim clearance and the minimum level is near the bushing. In the vortex area, the variation of $\bar{C}_{1 u}$ is close to linear.

At the exit from RB, over the most of working blade length, the value $\bar{C}_{2 u}$ is small $(<0.08 U R o)$, which corresponds to the influx of working fluid to the output edges of rotating working blades. The increase $\bar{C}_{2 u}$ in the peripheral area is caused by both the swirling of vortex by the main flow in the bushing tear-off and its swirling near the meridional rim. At the outer radius $C_{2 u} \approx C_{1 u}$, which is caused by leakage through the radial clearance.

The flow structure shown has a great influence on the temperature of the working medium. The temperature $t_{\mathrm{rb}}$ change along the length of the working blade, obtained experimentally [5] on a full-scale stand, depending on the pressure in the condenser at a constant flow rate of steam, is shown in Fig. 5. The maximum temperature measured at the outlet edges of the working blades is observed in the peripheral section and its level is determined by the temperature state of the vortex rotating in a rim clearance and in the middle part of the working blade $\bar{l}=0.5-0.6$ for which the main flow is affected by the temperature of



Fig. 4. Axial (a) and peripheral (b) components of velocity in the mode $\overline{G v} v_{2} \approx 0.05, P_{c}=29.4 \mathrm{kPa}$ 




Fig. 5. The change of temperature at the outputting edges along the height of the rotor blades (stage 31):

1 is $G=23.9 \mathrm{~kg} / \mathrm{s}, P_{c}=9.8 \mathrm{kPa} ; 2$ is $G=23.9 \mathrm{~kg} / \mathrm{s}, P_{c}=12.7 \mathrm{kPa}$; 3 is $G=24.7 \mathrm{~kg} / \mathrm{s}, P_{c}=14.7 \mathrm{kPa}$; 4 is $G=24.7 \mathrm{~kg} / \mathrm{s}$, $P_{c}=19.6 \mathrm{kPa} ; 5$ is $\mathrm{G}=24.7 \mathrm{~kg} / \mathrm{s}, P_{c}=29.4 \mathrm{kPa}$; $\bullet$ is the temperature of the moisture trap ring

the bushing tear-off at the exit of RB. The decrease in temperature in the root area is caused by the inflow of colder steam from the condenser.

Next, we consider the problem of estimating power consumption at the low-flow rate modes.

\section{THE POWER CONSUMPTION OF STAGES WITH A SMALL BUSHING RATIO}

Since during the operation of stage three processes of different physical nature are formed, then to determine the temperature state of stage it is necessary to evaluate the characteristics of these processes, which is a very difficult task. Therefore, at the first step, an integral determination of the power consumption in the stage was performed when the mode of its operation changed.

A study of the series of authors [9-12] showed that it is most advisable to use the Zuter-Traupel dependence

$$
N_{V}=C \cdot \frac{\pi D_{\text {mid }} l_{\mathrm{rb}}}{2} \rho_{\text {mid }} U_{\text {mid }}^{3}
$$

where the coefficient $C$ depends on both geometric and mode factors and the steam density $\rho$ is determined by the parameters of steam in the stage, $U_{\text {mid }}=\omega \cdot r_{\text {mid }}$ is the peripheral velocity on the middle radius, $\omega$ is the rotation frequency of rotor, and $r_{\text {mid }}$ is the middle radius.
The influence analysis of the geometric characteristics of stages with different bushing ratios and the geometry of the blade apparatus allowed us to present a formula for determining the coefficient $C$ in the form of a dependence on the relative volumetric consumption

$$
\begin{aligned}
& C=C_{0} \cdot\left[1-0.30 \cdot \overline{\overline{G v_{2}}}+\right. \\
& \left.0.60 \cdot\left(\overline{\overline{G v_{2}}}\right)^{2}-1.30 \cdot\left(\overline{\overline{G v_{2}}}\right)^{3}\right],
\end{aligned}
$$

where $\overline{\overline{G v_{2}}}$ is the volumetric flow rate of steam in relation to the volumetric flow rate of steam at the idle mode $\overline{\overline{G v_{2}}}=\frac{\overline{G v_{2}}}{\left(\overline{G v_{2}}\right)_{\text {idle }}}$;

$$
\begin{aligned}
& C_{0}=0.04+[0.09+5.629 . \\
& \left.\left(1-1.0786 \cdot \operatorname{tg} \beta_{2 \text { ef }}^{\text {mid }}\right) \cdot \frac{B_{\text {mid }}}{D_{\text {mid }}}\right] \cdot \frac{l_{\mathrm{rb}}}{D_{\text {mid }}},
\end{aligned}
$$

where $\beta_{\text {2ef }}^{\text {mid }}$ is the effective angle of flow exit on the middle diameter, and $B_{\text {mid }}$ is the axial width of working blade.

Equation (5) is obtained for the stage with cylindrical contours. If there is a peripheral contour in the stator blades that forms a protrusion of height $h$ in the rim clearance, a correction is introduced for the calculation of influence of this protrusion

$$
C_{0}=\mathrm{C}_{0(h=0)}-0.283 \bar{h}, \bar{h}=h / l_{\mathrm{rb}} .
$$

For the values of protrusions $\bar{h}>0.11$ in the stages with large values $0<\bar{h} \leq 0.5$, it can be assumed that the value $C_{0} \approx 0.108$.

\section{CONCLUSIONS}

1. The flow structure in the high fan stage is analysed. There are three processes of its formation, the appearance of which is accompanied by flow breakdowns both behind the rotor blades (bushing tear-off) and in the rim clearance of the stage (rotating vortex). Also the change in the structure of the main flow moving from the root to the peripheral area of the blade.

2. The appearance of these zones is accompanied by an increase in temperature from the saturation temperature to the maximum values 
exceeding $300^{\circ} \mathrm{C}$. First of all, the steam overheating occurs in the mass of the rotating vortex at $\bar{G} v_{2} \leq\left(\overline{G v}_{2}\right)$ idle after the evaporation of finely dispersed moisture.

3. The integral determination of power consumption in a stage when changing its operating mode using the Zuter-Traupel formula, in which the proportionality coefficient is refined with respect to the stages with a small bushing ratio, is presented. It is shown that in this case it depends on the ratio of the volumetric flow rate of steam to the volumetric flow rate of idle and the geometric characteristics of the stage.

Received 27 January 2020 Accepted 20 March 2020

\section{References}

1. Shubenko A. L., Goloshchapov V. N., Bystritsky L. N., Agafonov B. N., Alekhina S. V., Kasilov V. I. Steam Turbines: Little Consumable Modes of Low Pressure Stages. St. Petersburg: Energotech, 2018. 344 p.

2. Arakelyan E. K., Pikina G. A., Andryushin A. V., Mezin S. V., Andryushin K. A., Kosoy A. A., Pashchenko F. F. Features of steam turbine stages operation in low-flow modes when modeling hydrodynamic processes in the turbine in steamless and motor modes. Procedia Computer Science. 2020. Vol. 170. P. 935-940.

3. Karakurt S. A., Güneş Ü. Performance analysis of a steam turbine power plant at part load conditions. Journal of Thermal Engineering. 2017. Vol. 3. No. 2. P. 1121-1128.

4. Delabriere H., Werthe J. M. Through-flow analysis of steam turbines operating under partial admis- sion. Direction des Etudes et Recherches CHATOU (France). 1994. Vol. 1. P. 1-14.

5. Uryev E. V., Lokalom S. A., Maslennikov L. N., Fuchsman L. D., Vislova V. M. Investigation of the thermal state of low-pressure part of T-250/300-240 turbine. Heat Power Engineering. 1985. No. 3. P. 61-63.

6. Khaimov V. A. Little Consumable Modes of Low-pressure of T-250/300-240 Turbine. St. Petersburg: BHV-Petersburg, 2007. 240 p.

7. Zhuchenko L. A., Ermolaev V. V., Kortenko V. V. Vibration researches of impellers of low-pressure parts of OAO TMZ turbines. Heat Power Engineering. 2001. No. 4. P. 62-67.

8. Khaimov V. A., Varapaev Yu. A. Extreme temperature modes of low-pressure part turbine T-250/300-23.5. Heat Power Engineering. 1994. No. 7. P. 44-48.

9. Ponomarev V. N. Research of the operation of the turbine stage in partial modes. Power Engineering. 1976. No. 2. P. 11-13.

10. Bystritsky L. N., Goloshchapov V. N., Kasilov V. I., Kozlokov A. Yu., Shubenko A. L. Analysis of calculated dependences for determining ventilation losses in turbine stages. East European Journal of Advanced Technology. 2006. No. 1/2(19). P. 183-189.

11. Neuimin V. M. Mathematical dependences for evaluating ventilation power losses in the stages of axial turbomachines and their analysis. New in Russian Energy (NRE). 2004. No. 10. P. 24-42.

12. Matveenko V. A., Agafonov B. N. Features of the low-pressure part operation of steam turbines at low flow rates. Power Engineering: Overview. 1984. No. 12. P. 54. 
A. L. Shubenko, V. N. Goloshchapov, D. O. Senetska

\section{MAŽŲ SRAUTŲ REŽIMŲ PASKUTINĖS}

\section{PAKOPOS TURBINOS VEIKIMAS}

Santrauka

Šiluminès ir kogeneracinès elektrinès veikia nuolatos besikeičiančiais režimais, t. y. beveik kasdien jos visiškai nukraunamos, išjungiamos savaitgaliais ir švenčių dienomis, o paskui ịvairių šiluminių būsenų įrenginiai paleidžiami. Paleidžiant ar veikiant daliniu apkrovimu, taip pat išjungimo metu pratekančio per turbiną srauto greičiai yra maži, todèl atsiranda įvairūs (nu)plèšimo reiškiniai, kurie priklauso nuo santykinio tūrinio garo srauto $\bar{G} v_{2}$ žemo slègio cilindre, pradedant nuo paskutinès pakopos.

Tai ypač būdinga srautui tekant kogeneracinių turbinų žemo slègio cilindre. Mažų srautų režimų metu pratekančio srauto struktūra keičiasi, atsiranda ịvorių plěšiamieji reiškiniai, tarp rotoriaus ir statoriaus menčių atsiranda besisukantys sūkuriai, o kai pereinama i kompresoriaus darbo réžimą, tekančio srauto slègis mažèja.

Formuojantis plyšimo vietai garų temperatūra perkaitimo metu labai padidèja, nes dèl sūkurių struktūros šioje zonoje atsiranda ventiliavimo nuostolių.

Nagrinëjant temperatūros pokytị išilgai darbinès mentès ilgio darbe išryškinami būdingi šio pokyčio taškai, atsižvelgiant ị santykinị tūrinị garo srautą.

Nustatytos šlapio garo virsmo perkaitinto garo srautu ribos mažejant $\bar{G} v_{2}$. Ivertintas energijos suvartojimas turbinos pakopos darbo metu, kai garo srautas mažèja ir keičiasi jo struktūra.

Raktažodžiai: turbinos pakopos, mažo srauto greičio režimas, garų temperatūra, energijos suvartojimas 